\title{
OPEN Calorimetry, physicochemical characteristics and nitrogen release from extruded urea
}

\author{
Noemila Debora Kozerski, Luís Carlos Vinhas Ítavo ${ }^{\bowtie}$ Camila Celeste Brandão Ferreira Ítavo, \\ Gelson dos Santos Difante, Alexandre Menezes Dias, Lincoln Carlos Silva de Oliveira, \\ Elias Nogueira de Aguiar, Alexandre Guimarães Inácio, Antonio Leandro Chaves Gurgel \& \\ Geraldo Tadeu dos Santos
}

Our hypothesis was that extrusion of urea associated with corn may reduce $\mathrm{N}$ solubilization and increase the nutritional quality of this food for ruminants. We aimed to physically and chemically characterize a corn and urea mixture before and after the extrusion process. It was evaluated morphological differences by scanning electron microscopy, nitrogen solubilization, and compound mass loss by thermogravimetry. In scanning electron microscopy, extruded urea showed agglomerated and defined structures, with changes in the morphology of starch granules and urea crystals, differing from the arrangement of the corn and urea mixture. The extruded urea maintained a constant nitrogen release pattern for up to $360 \mathrm{~min}$. In thermogravimetry, extruded urea presented a higher temperature to initiate mass loss, that is, the disappearance of the material with increasing temperature, but the mass loss was lower when compared to the first event of the corn and urea mixture. In conclusion the process of extrusion of urea with corn modifies the original structures of these ingredients and controls the release of nitrogen from the urea, maintaining in its formation an energy source optimizing the use of nitrogen by ruminal bacteria, because the more synchronized the release of starch (energy) and nitrogen, the better the use by ruminal microorganisms.

The use of urea as a source of non-protein nitrogen (NNP) for ruminants is widespread and has been universally accepted as a cheap ingredient to replace plant protein sources in ruminant diets ${ }^{1}$, as ruminal bacteria have the ability to convert ammonia $\left(\mathrm{NH}_{3}\right)$ to high biological value microbial protein when in sync with available energy ${ }^{2}$.

With the increased use of concentrates and urea in the ruminant diet, studies intensified concerning the development of products that controlled the release of $\mathrm{N}$ from urea and an extruded starch product was developed, cereals with urea ${ }^{3,4}$ and a $45 \%$ protein equivalent ${ }^{5}$. The extrusion process consists of the fusion of urea with the gelatinized starch molecule, upon exposure to pressure, temperature, and humidity, for a certain time, thus obtaining the extruded urea called starea. Urea changes from a crystalline to a non-crystalline structure, which is found within the gelatinized portion of $\operatorname{starch}^{3-5}$.

This practice can increase the speed of rumen starch fermentation and reduce the intensity of ammonia release from urea, synchronizing both factors for microbial protein synthesis ${ }^{6}$ and increase the acceptability of urea by animals in concentrates ${ }^{7}$. Improvement of extruded urea production techniques, increase of protein equivalent to $200 \%$ crude protein (CP) levels, and utilization for various productive purposes in ruminants has intensified, demanding research aiming to characterize the modifications that processing promotes in the ingredients used, as the demand for use of alternative products is increasing in ruminant diets.

However, comparisons between urea and starea (extruded urea) on nitrogen release in lambs ${ }^{8,9}$ or in lactating cows ${ }^{10}$ have presented different results, not allowing a conclusion on the subject. It is known that in finishing steers a lower concentration of ruminal ammonia is observed in the treatment with starea when compared to a mixture of urea plus coarse sorghum after seven days of feeding ${ }^{11}$. Thus, the hypothesis of this study is that extruded urea may reduce $\mathrm{N}$ solubilization compared to urea mixed with maize. Therefore, the objective was to evaluate the characteristics of extruded urea and compare them with the corn and urea mixture before the extrusion process. 

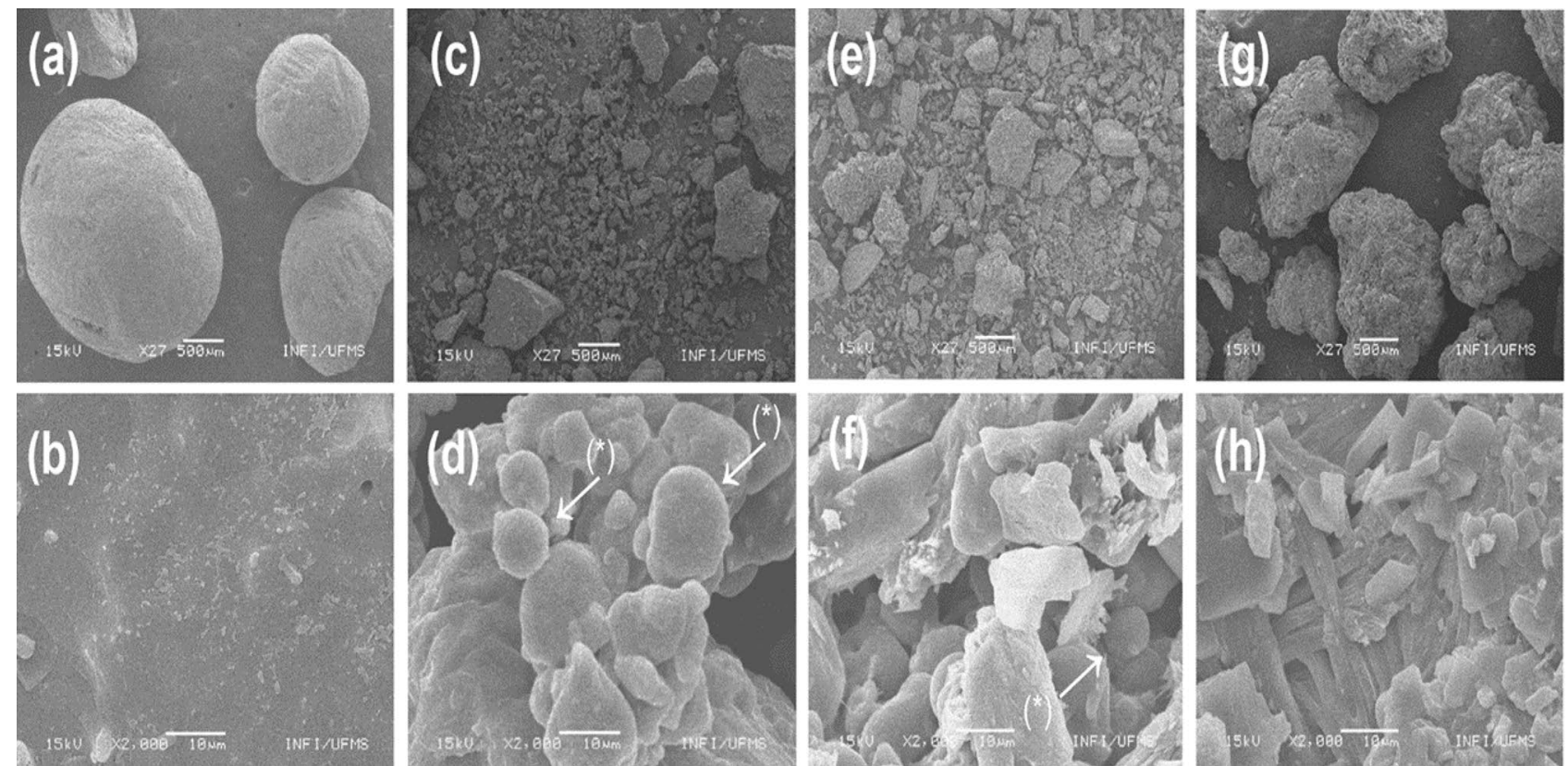

Figure 1. Scanning electron microscopy at 27 and 2000 times increases in urea (a and b), ground corn (c and $\mathbf{d})$, corn and urea mixture (e and $\mathbf{f}$ ), and extruded urea (g and $\mathbf{h})$. $\left(^{\star}\right)$ Starch granules.

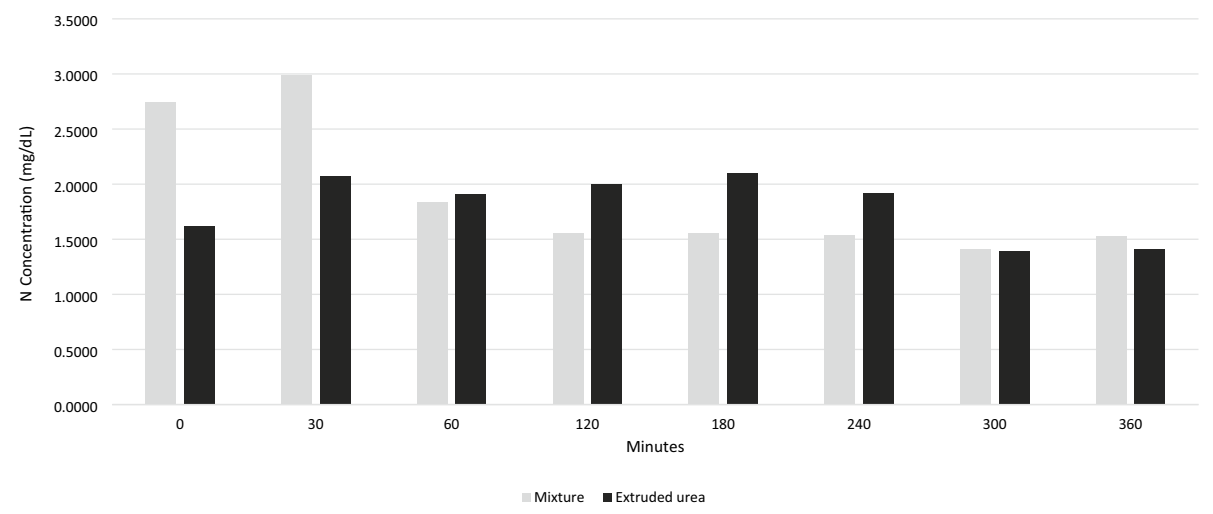

Figure 2. Nitrogen solubility $(\mathrm{mg} / \mathrm{dL})$ in water as a function of in vitro incubation time at $39^{\circ} \mathrm{C}$.

\section{Results}

Scanning electron microscopy (SEM). Urea has in its original form spherical shapes (Fig. 1a and b). The ground whole corn, is configured in a dispersed structure, being possible to evidence the starch granules, defined by rounded shapes (Fig. 1c and d). The mixture of corn and urea is dispersed in the carbon strip, without having a definite shape, with the presence of starch granules, defined by rounded shapes, and gleaming crystalline structures of urea (Fig. 1e and f). In the extruded urea sample, structures in defined shapes and agglomerates are observed, which formed a complex structure (Fig. $1 \mathrm{~g}$ and h).

In vitro nitrogen solubility. The $\mathrm{N}$ release peak of the maize and urea sample (Fig. 2) occurred within 30 min $\left(\mathrm{Y}_{\text {corn_and_urea_mixture }}=2.8219-0 ; 2059 \mathrm{x} ; \mathrm{R}^{2}=0.6722\right)$.

The reduction in the rate of nitrogen solubilization in the aqueous medium of the extruded urea sample (Fig. 2) evidenced the slower solubilization of $\mathrm{N}$ compared to the corn and urea mixture sample $\left(\mathrm{Y}_{\text {extruded_urea }}=2.0578-0.0565 \mathrm{x} ; \mathrm{R}^{2}=0.2313\right)$.

Thermogravimetry and derived thermogravimetry. The urea sample was characterized in the TG and DTG curves with five simultaneous stages, that is, the reactions of an event do not end with beginning of the next event. This is evident in the first and second stages, which initiate the decomposition of urea between temperatures of approximately 133.0 and $180.5 \mathrm{C}$, with loss of most mass, estimated at $72.97 \%$ (Table 2). These stages were characterized by the fast and narrow peak DTG (Fig. 4). 


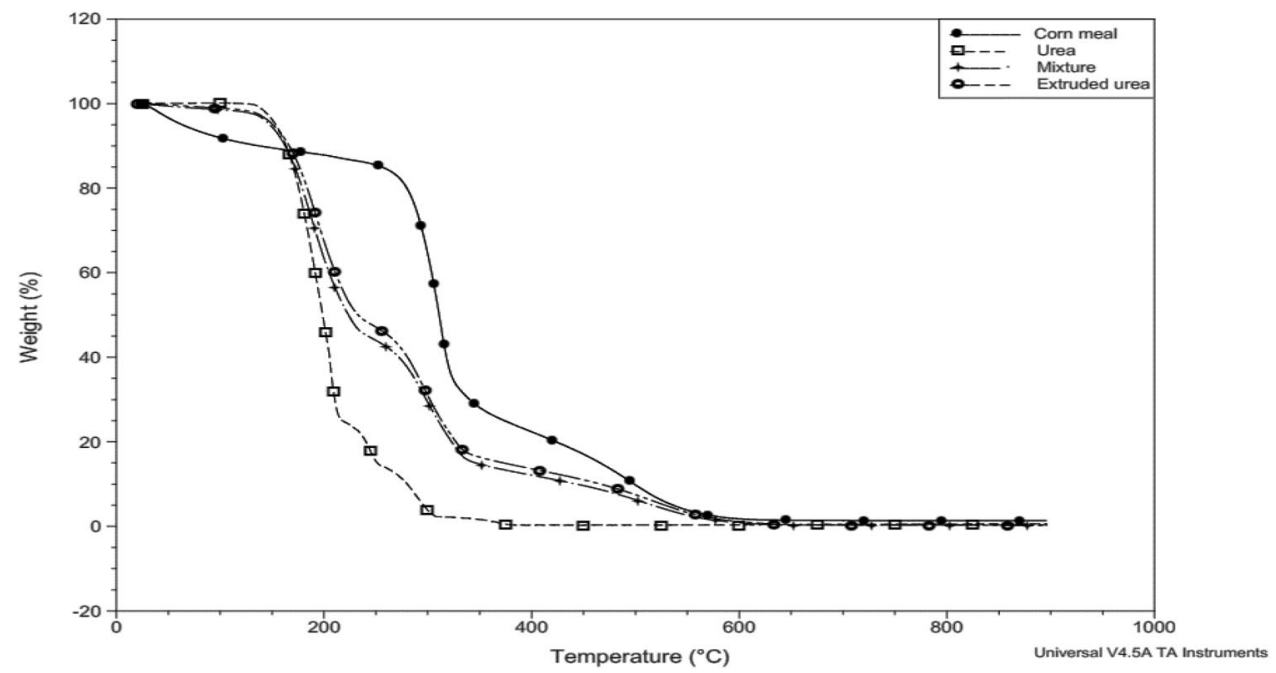

Figure 3. Overlapping TG curves of urea, ground corn, mix corn and urea, and extruded urea.

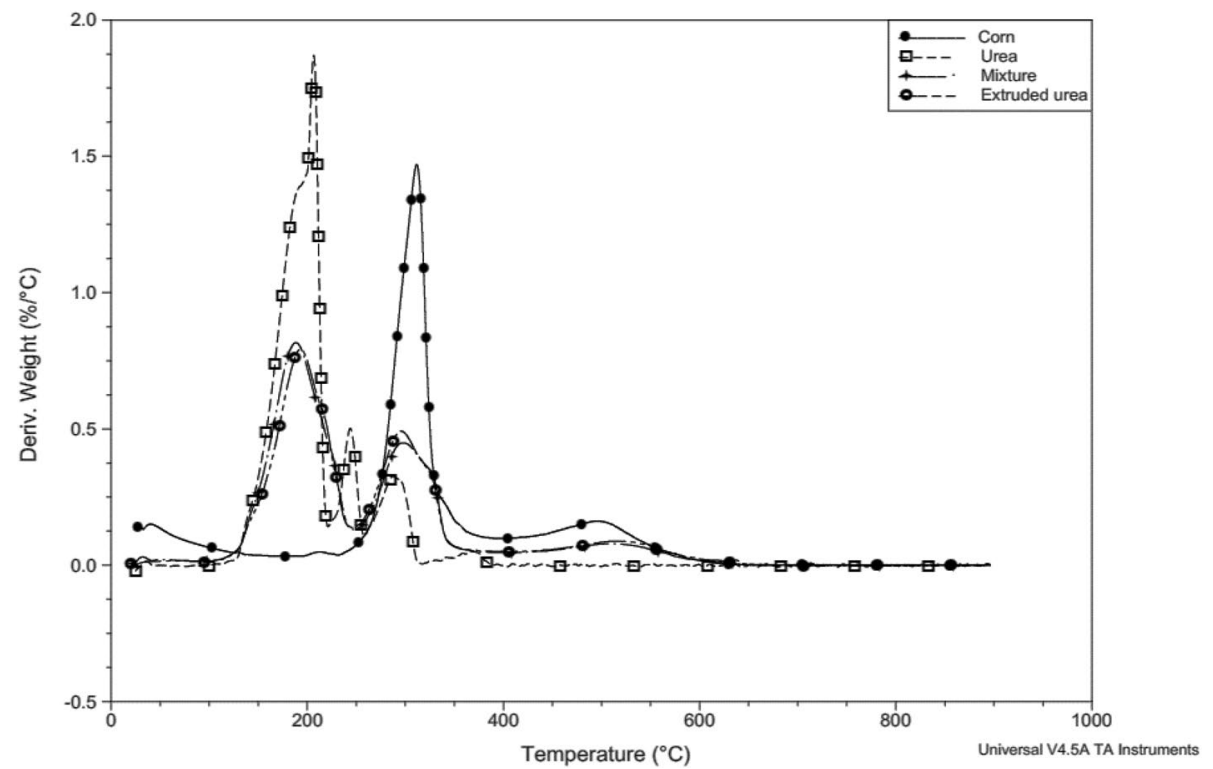

Figure 4. Overlapping DTG curves of urea, ground corn, mix corn and urea, and extruded urea.

Stages three and four (Table 2), characterized by DTG peaks, maintained the concurrency with milder mass loss than in the first and second stages. The fifth stage presented a wider peak in the DTG (Fig. 4), which characterizes the end of urea decomposition.

The sample of ground whole corn showed no stability (Table 2). The second stage was characterized by a mass loss of rapidly leaving matrix compounds, demonstrated by a narrow and rapid peak (Fig. 4). In this event, the DTG peak temperature indicated that the reaction occurred faster at $310.86^{\circ} \mathrm{C}$ (Table 2). The third event was characterized by a slow, broad-derivative peak reaction corresponding to the physical or chemical interactions with the sample matrix (Fig. 3).

The sample of corn and urea mixture, and extruded urea presented three stages (Table 2 and Fig. 3). None of the samples presented constant stability, which indicates the water loss caused by the presence of corn, included in the same proportion for both samples (26.8\%).

In the sample composed of corn and urea, the decomposition started at approximately $103.5{ }^{\circ} \mathrm{C}$ and the extruded urea at $136.2^{\circ} \mathrm{C}$, with the loss of mass recorded by the two samples in proportions of $54.9 \%$ and $50.5 \%$, respectively (Table 2).

Similar behavior was observed in the second stage on the DTG curve (Fig. 4) of samples of corn and urea mixture, and extruded urea (Fig. 3), but the temperature of the beginning of mass variation (Table 2) was higher for extruded urea $\left(231.7^{\circ} \mathrm{C}\right)$ than for the corn and urea mixture sample $\left(228.3^{\circ} \mathrm{C}\right)$. 


\begin{tabular}{|l|c|c|}
\hline Components (g/kg DM) & Mixture & Extruded urea \\
\hline Dry matter (g/kg) & 961.4 & 961.0 \\
\hline Organic matter & 995.4 & 995.7 \\
\hline Crude protein (n-total $\times 6,25)$ & 2040.4 & 2029.7 \\
\hline NPN (Fraction A) & 292.3 & 298.1 \\
\hline CP from NNP (Fraction A) & 1826.7 & 1863.3 \\
\hline N soluble (Fraction B1) & 17.1 & 13.3 \\
\hline CP from N (Fraction B1) & 106.9 & 83.2 \\
\hline N-True protein (Fraction B2) & 8.83 & 5.22 \\
\hline CP from N (Fraction B2) & 55.2 & 32.7 \\
\hline N-True protein (Fraction B3) & 2.2 & 2.4 \\
\hline CP from N (Fraction B3) & 13.7 & 15.0 \\
\hline N insoluble neutral detergent & 7.9 & 7.8 \\
\hline N insoluble acid detergent (Fraction C) & 6.1 & 5.7 \\
\hline CP from N (Fraction C) & 37.9 & 35.6 \\
\hline Ethereal extract & 32.5 & 31.6 \\
\hline Total carbohydrates & 271.1 & 278.4 \\
\hline Non-fibrous carbohydrates & 194.5 & 218.0 \\
\hline Neutral detergent fiber & 52.0 & 32.5 \\
\hline Acid detergent fiber & 21.6 & 18.3 \\
\hline
\end{tabular}

Table 1. Nutritional characterization of the mixture of ground corn and urea, and extruded urea.

\begin{tabular}{|c|c|c|c|c|c|}
\hline Sample & Stage & $\mathrm{T}_{\mathrm{a}}\left({ }^{\circ} \mathrm{C}\right)^{1}$ & $\mathrm{~T}_{\mathrm{b}}\left({ }^{\circ} \mathrm{C}\right)^{2}$ & Weight loss (\%) & Residue (\%) \\
\hline \multirow{5}{*}{ Urea } & 1 & 133.0 & 190.4 & 0.2 & \multirow{5}{*}{0.47} \\
\hline & 2 & 180.5 & 206.0 & 72.9 & \\
\hline & 3 & 213.9 & 243.1 & 13.4 & \\
\hline & 4 & 257.0 & 288.3 & 11.8 & \\
\hline & 5 & 305.1 & 369.2 & 1.9 & \\
\hline \multirow{3}{*}{ Ground corn grain } & 1 & 37.2 & 212.6 & 12.3 & \multirow{3}{*}{1.3} \\
\hline & 2 & 225.6 & 310.8 & 61.2 & \\
\hline & 3 & 372.5 & 496.6 & 23.6 & \\
\hline \multirow{3}{*}{ Mix corn and urea* } & 1 & 103.5 & 188.7 & 54.9 & \multirow{3}{*}{0.32} \\
\hline & 2 & 228.3 & 296.2 & 31.07 & \\
\hline & 3 & 335.7 & 513.9 & 15.62 & \\
\hline \multirow{3}{*}{ Extruded urea* } & 1 & 136.2 & 194.5 & 50.57 & \multirow{3}{*}{0.34} \\
\hline & 2 & 231.7 & 294.9 & 34.32 & \\
\hline & 3 & 336.2 & 524.5 & 14.65 & \\
\hline
\end{tabular}

Table 2. Characterization of steps, temperature of onset of mass loss, temperature of the highest reaction rate, mass loss and residue of urea, ground corn, ground corn and urea mixture, and extruded urea in air atmosphere with heating ratio of $10{ }^{\circ} \mathrm{C}$ per $\mathrm{min}^{-1} .{ }^{1}$ Temperature obtained by Weight Loss temp method. ${ }^{2} \mathrm{DTG}$ peak temperature. ${ }^{\star} 200 \%$ protein equivalent $(700 \mathrm{~g} / \mathrm{kg}$ urea, $268 \mathrm{~g} / \mathrm{kg}$ ground whole corn and $32 \mathrm{~g} / \mathrm{kg}$ sulfur flower).

The third stage showed similarities in mass decomposition (Table 2) in the sample corn and urea mixture, and extruded urea (15.6 and 14.6\%, respectively) and in the DTG (Fig. 4) the derivative peak was more extensive when compared to the first steps.

\section{Discussion}

Using the images obtained from SEM it is possible to morphologically differentiate that the extrusion process alters the original structures of urea (Fig. 1a and b) and corn (Fig. 1c and d), attributed to the thickened shape and to modifications such as the disappearance of the starch granules (Fig. 1h) which was possibly caused by high pressure, temperature, and humidity. The extrusion gelatinized the starch and involved the non-crystalline structure of urea, which formed a complex structure. These characteristics of extruded urea make $\mathrm{N}$ release slower and more gradual (Fig. 2), which may improve utilization by rumen bacteria ${ }^{2}$ associated with the energy source of corn starch, can increase the synthesis of microbial proteins in the ruminant animals. 
The rapid $\mathrm{N}$ solubilization of the maize and urea sample is evidenced by the maintenance of the original forms obtained by SEM images (Fig. 1e and $\mathrm{f}$ ) and about $90 \%$ of the sample nitrogen is represented by fraction A, which is the non-protein soluble nitrogen from urea (Table 1). This behavior indicates that carbohydrate must be rapidly soluble and in sufficient amount to synchronize with $\mathrm{NH}_{3}$ and promote microbial protein synthesis. The constancy of $\mathrm{N}$ release at other times are contributions from fractions B1, B2, and B3 of corn $\mathrm{N}$ (Table 1), which are more slowly degraded fractions.

The reduction in the rate of nitrogen solubilization in the aqueous medium of the extruded urea sample (Fig. 2) with even fraction A representing $90 \%$ of the nitrogen present in the sample (Table 1), can be evidenced by the grouping of structures observed in Fig. 1 ( $g$ and $h$ ), which configures a structural change of starch and urea after the extrusion process. Most of the $\mathrm{N}$ present in the samples belonging to the A fraction of the protein, also justifies the peak of $\mathrm{N}$ release that around $30 \mathrm{~min}$. The constant $\mathrm{N}$ release pattern of this sample, observed up to $360 \mathrm{~min}$, would allow rumen free ammonia to be used by rumen microorganisms along with rumen degradable carbohydrates at different speeds to synthesize microbial protein and prevent $\mathrm{NH}_{3}$ losses.

The rate of $\mathrm{N}$ release should be dependent on the rate of degradation of the carbohydrate source, where ammonia production in synergism with ruminal content energy metabolism is a decisive factor in microbial protein formation ${ }^{6}$.

The excess of $\mathrm{N}$ due to the high solubility of urea (Fig. 2) may, besides causing toxicity, constitute an energy waste as it requires energy to eliminate excess ammonia in the blood, negatively impacting the environment, with health and economic implications ${ }^{12}$.

Protein utilization efficiency in ruminants can be improved by maintaining adequate NNP amounts and feeding management with the use of extruded urea in cattle diets. Up to the level of supplementation of $80 \mathrm{~g} / 100 \mathrm{~kg}$ body weight of extruded urea (starea with protein equivalent $200 \% \mathrm{CP}$ ) there are no negative influences on the rumen environment ${ }^{13}$.

Industry has improved to facilitate the use of NNP in ruminant diets, such as the urea extrusion process, to prevent ammonia poisoning and increase the availability of rumen nitrogen for microbial synthesis ${ }^{14}$. The urea sample showed thermal stability to its melting point at $133.0^{\circ} \mathrm{C}^{15}$.

When less mass loss occurs in the urea sample, in stages three and four (Table 2), it demonstrates that the complex polymerization and depolymerization reactions of high molecular weight compounds occurred and continued ${ }^{16}$.

The gaseous products generated by urea pyrolysis are between temperatures from 132 to $190^{\circ} \mathrm{C}$. Experimental results show that at 132.5 to $160^{\circ} \mathrm{C}$, urea was only involved in consuming reactions. Biuret and cyanuric acid formation reactions, rather than the decomposition reaction of urea, occupy the major part of urea consumption. Above $160^{\circ} \mathrm{C}$, the dominant reaction of cyanide passes to decomposition formation, while the conversion temperature point of the biuret is $170{ }^{\circ} \mathrm{C}$. $\mathrm{NH}_{3}$ production fluctuates at $132.5-170{ }^{\circ} \mathrm{C}$, but continues to rise between 170 and $190^{\circ} \mathrm{C}^{17}$. In atmosphere with $5 \%$ or $10 \% \mathrm{O}_{2}$, the highest $\mathrm{NH}_{3}$ production was reached at $200 \mathrm{C}^{15}$.

The instability of the sample of ground whole corn was characterized by the loss of water, possibly by starch hydroxyls (Table 2). The second stage was characterized by a mass loss of rapidly leaving matrix compounds (Fig. 4), possibly by the decomposition of larger chain carbons and there were few physical or chemical interactions between the exiting compound and the sample matrix ${ }^{16}$.

The presence of water influenced the thermal stability of the corn and urea mixture sample, as it acts as a plasticizer in starch crystals, which may decrease the glass transition temperature and consequently the melting temperature of the crystals ${ }^{18}$ as evidenced in the whole corn sample (Fig. 3 ).

The delay in the onset of extruded urea decomposition and lower mass loss is possibly due to starch gelatinization, which after this process loses its initial structural organization, hydrogen bonds are broken, with crystalline fusion $^{3}$, being the degree of gelatinization, higher for extruded foods, as the temperature used in the process is higher, up to $250^{\circ} \mathrm{C}$ versus $60-95^{\circ} \mathrm{C}^{19}$. In addition, cornmeal produced by the dry milling process of maize grain has in its composition a higher proportion of starch, between 50 and $55 \%, 10 \%$ protein, $1 \%$ lipid $^{20}$.

In the second stage on the DTG curve (Fig. 4) the temperature of the beginning of mass variation (Table 2) was higher for extruded urea which indicates that the extrusion process delays mass loss.

The characterization of extruded urea provides a detailed behavior of the product during its use, which allows its inclusion according to the characteristics of the animal and different nutritional management.

\section{Conclusions}

We recommend the extrusion process to reducing $\mathrm{N}$ solubilization of nitrogen products and increasing nutritional quality of end product. The extrusion process of urea and corn to obtain extruded urea (starea) modifies the structure, increase the quality by starch gelatinization and complexation with the crystals of urea, and preventing rapid solubilization of nitrogen.

\section{Materials and methods}

Samples and nutritional characterization. Samples of two products denominated corn and urea mixture were used, corresponding to the mixture of ingredients before extrusion and extruded urea-Starea (Amiréia Pajoara 200S). The production process of extruded urea consists of the complexation of urea with a starch molecule gelatinized, using pressure, temperature and humidity, thus obtaining the starea. The two samples, with a protein equivalent of $200 \%$, were composed of livestock urea, ground corn grain, and sulfur flower in the proportions of $70 \%, 26.8 \%$, and $3.2 \%$, respectively ${ }^{3}$.

The two ingredients were sent for chemical analysis in the original particle size in order to test the processing effect. Dry matter (DM; Table 1) was determined by drying in an oven at $105^{\circ} \mathrm{C}$ overnight (method $930.15^{21}$ ). The total nitrogen content was quantified by the Kjeldahl method using the Tecnal TE-036/1 distiller (Tecnal, 
Piracicaba, Brazil) (method 976.05 ${ }^{21}$ ). The determination of ether extract was performed on an Ankom XT 10 extractor apparatus (Ankon Technology, NY, USA). The ash content was determined by muffle incineration (method $942.05^{21}$ ) and the organic matter $(\mathrm{OM})$ content was calculated by the difference between 100 and the ash percentage. To determine the neutral detergent fiber (NDF) ${ }^{22}$ content, thermostable $\alpha$-amylase (Termamyl 120 L Sigma-Aldrich, 3050 Spruce Street, Saint Louis, MO, USA) and the results were expressed with residual ash. Were determined the percentage of total carbohydrates (TC) ${ }^{23}$ and non-fibrous carbohydrates (NFC) ${ }^{24}$.

Protein fractions were determined according to the methodology ${ }^{25}$ described with fraction A corresponding to NPN, B1 corresponding to true soluble protein, B2 o N to rumen-insoluble true protein, but not bound to NDF, B3 corresponding to potentially available N-linked fiber (insoluble nitrogen in neutral detergent), and C the unavailable portion, linked to lignin (acid detergent insoluble nitrogen).

Scanning electron microscopy (SEM) observations. The study of sample morphology (Fig. 1) was performed by scanning electron microscopy (SEM) measurements on JEOL model JSM 6380LV equipment at Physics Institute of Federal University of Mato Grosso do Sul (INFI/UFMS).

Samples in the original form of urea, ground corn grain, corn and urea mixture, and extruded urea were dispersed on double-sided carbon tape for attachment to the top of a copper stub. The set was taken into the sputtering chamber (Denton Vacuum, Desk III model) for the deposition of a thin gold layer on the surface of the dust particles to obtain a better SEM image resolution and increased conductivity of the sample to avoid the effects of electronic loading that impair image resolution. For the analysis, a voltage of $15 \mathrm{kV}$, working distance (WD) $12 \mathrm{~mm}$, and spot size 20 were used. Readings were taken and images were recorded at 27 and 2000 times increases for comparative morphology purposes.

In vitro nitrogen solubility. To estimate nitrogen $(\mathrm{N})$ release in different products, the Kjeldahl method was used to determine total nitrogen, with modifications ${ }^{17}$.

Initially $2 \mathrm{~g}$ of the sample composed of ground corn and urea and extruded urea (starea) were packed in glassware of $500 \mathrm{~mL}$ capacity. Then $200 \mathrm{~mL}$ of distilled water was added and the samples were taken to the water bath $\left(39.5^{\circ} \mathrm{C}\right)$ in stirring. The total analysis time was $360 \mathrm{~min}$, and a $2 \mathrm{~mL}$ aliquot (in triplicate) was removed from the supernatant at times $0,30,60,120,180,240,300$ and $360 \mathrm{~min}$, according to methodology described to Ítavo et al. ${ }^{6}$.

These aliquots were packed into digestion tubes containing $5 \mathrm{~mL}$ of $2 \mathrm{~N}$ potassium hydroxide $(\mathrm{KOH})$ and $13 \mathrm{~mL}$ of distilled water. Subsequently, the digestion tubes were taken to the nitrogen distiller (TECNALTE-036/1). In the same equipment an Erlenmeyer containing $10 \mathrm{~mL}$ of $2 \%$ boric acid was also coupled and then distillation occurred until obtaining $75 \mathrm{~mL}$ of solution.

Finally, titrations of the recovered solutions were made in the distiller, with $0.005 \mathrm{~N}$ of hydrochloric acid $(\mathrm{HCl})$ used until the turning point of the solutions was obtained. As with distillation, titration was also performed in triplicate for each product and for each analysis time. A blank (distilled water only) was also performed at the beginning of each analysis time to verify equipment contamination.

The data obtained with the titrations were submitted to the following equation: $\mathrm{N}$ concentration $(\mathrm{g} / \mathrm{dL})=\mathrm{HCl}$ volume used $\mathrm{x} \mathrm{HCl}$ correction factor $\times 0.005 \times 0.014 \times 100 / 2$.

Thermogravimetry and derived thermogravimetry measurements. The thermogravimetry (TG) and derivative thermogravimetry (DTG) curves of the original urea, ground whole corn, corn and urea mixture, and extruded urea samples were determined with a TGA Q50 V20.13 thermogravimetric analyzer, Build 39 (New Castle, USA), at Chemical Institute of Federal University of Mato Grosso do Sul. About $6.0 \mathrm{mg}$ of each sample was weighed on platinum cell and the tests were carried out in a synthetic air atmosphere, with a heating rate of $10{ }^{\circ} \mathrm{C} \mathrm{min}{ }^{-1}$, from room temperature to $900{ }^{\circ} \mathrm{C}$. The temperatures at which the decomposition rate of the sample was maximum (Td) were obtained through the DTG curves. Data were analyzed using Advantage/ Universal Analyzes Software v5.5.24 available from TA Instruments.

Ethics statement. All plant studies and sampling were carried out in accordance with relevant institutional, national or international guidelines. We used ground corn grain (Zea mays) commercial.

Received: 22 March 2021; Accepted: 20 August 2021

Published online: 15 September 2021

\section{References}

1. Patra, A. K. \& Aschenbach, J. R. Ureases in the gastrointestinal tracts of ruminant and monogastric animals and their implication in urea-N/ammonia metabolism: A review. J. Adv. Res. 13, 39-50 (2018).

2. National Research Council (NRC). Nutrient Requirements of Dairy Cattle. (7th ed., National Academy Press, Washington, 2001).

3. Helmer, L. G., Bartley, E. E., Deyoe, C. W., Meyer, R. M. \& Pfost, H. B. Feed processing. V. Effect of an expansion-processed mixture of grain and urea (Starea) on nitrogen utilization in vitro. J. Dairy Sci. 53, 330-335 (1970).

4. Helmer, L. G., Bartley, E. E. \& Deyoe, C. W. Feed processing. VI. Comparison of Starea, urea and soybean meal as protein sources for lactating dairy cows. J. Dairy Sci. 53, 883-887 (1970).

5. Bartley, E. E. \& Deyoe, C. W. Starea as a protein replacer for ruminants-review of 10 years of research. Feedstuffs 47, 42-51 (1975).

6. Ítavo, L. C. V. et al. Combinações de fontes de nitrogênio não proteico em suplementos para novilhos Nelore em pastejo. Rev Bras Saúde Prod Anim. 17, 448-460 (2016).

7. Pires, A. V. et al. Total replacement of soybean meal by urea or starea in high grain diets for beef cattle. Pesq. Agrop. Bras. 39, 937-942 (2004).

8. Silva, J. F. C. et al. Valor nutritivo da palha de arroz suplementada com amiréia, fubá+uréia e farelo de soja. Pesq. Agrop. Bras. 29, 1475-14881 (1994). 
9. Salman, A. K. D. et al. Estudo do balanço nitrogenado e da digestibilidade da matéria seca e proteína de rações, para ovinos, suplementadas com amiréia, uréia ou farelo de algodão. Rev. Bras. Zootecn. 26, 179-185 (1997).

10. Teller, E. \& Godeau, J. M. Some attempts to improve the nutritive value of urea for dairy cows. 3. Its adjunction to fermentable carbohydrates: Starea. Arch. Anim. Nutr. 36, 541-550 (1986).

11. Stiles, D. A. et al. Starea, soybean-meal, and urea as nitrogen-sources for lactating cows. J. Dairy Sci. 58, 777-778 (1975).

12. Hynes, D. N., Stergiadis, S., Gordon, A. \& Yan, T. Effects of crude protein level in concentrate supplements on animal performance and nitrogen utilization of lactating dairy cows fed fresh-cut perennial grass. J. Dairy Sci. 99, 8111-8120 (2016).

13. Moraes, G. J. et al. Extruded urea could reduce true protein source in beef cattle diets. J. Anim. Physiol. Anim. Nutri. 103, 1283-1294 (2019).

14. Tedeschi, L. O., Baker, M. J., Ketchen, D. J. \& Fox, D. G. Performance of growing and finishing cattle supplemented with a slowrelease urea product and urea. Can. J. Anim. Sci. 82, 567-573 (2002).

15. Wang, D., Hui, S. \& Liu, C. Mass loss and evolved gas analysis in thermal decomposition of solid urea. Fuel 207, 268-273 (2017).

16. Ionashiro M. Giolito: Fundamentos da termogravimetria, Análise Térmica Diferencial e Calorimetria Exploratória Diferencial. (Giz Editorial, São Paulo, 2004).

17. Wang, D., Dong, N., Hui, S. \& Niu, Y. Analysis of urea pyrolysis in $132.5-190^{\circ}$ C. Fuel 242, 62-67 (2019).

18. Sjöö, M. \& Nilsson, L. Starch in Food: Structure, Function and Applications 2nd edn. (Woodhead Publishing, 2018).

19. Gómez, L. M., Posada, S. L. \& Olivera, M. Starch in ruminant diets: A review. Rev. Colomb. Cienc. Pecu. 29, 77-90 (2016).

20. Mothé, C. G., Damico, A. \& Machado, M. G. S. Thermoanalytical study, HPLC and physical and chemical cracking from corn industry co-product. Ciênc Tecnol Aliment. 25, 1-7 (2005).

21. Association of Official Analytical Chemistry (AOAC). Official Methods of Analysis, (17th ed. Gaithersburg, MD, 2000).

22. Mertens, D. R. Gravimetric determination of amylase-treated neutral detergent fiber in feeds with refluxing in beaker or crucibles: Collaborative study. J. AOAC Int. 85, 1217-1240 (2002).

23. Sniffen, C. J., O'Connor, J. D., Van Soest, P. J., Fox, D. G. \& Russell, J. B. A net carbohydrate and protein system for evaluating cattle diets II Carbohydrate and protein availability. J. Anim. Sci. 70, 3562-3577 (1992).

24. Hall, M.B. Neutral Detergent-Soluble Carbohydrates. Nutritional Relevance and Analysis. A Laboratory Manual. (Gainesville: University of Florida 2000)

25. Licitra, G., Hernandez, T. M. \& Van Soest, P. J. Standardization of procedures for nitrogen fractionation of ruminant feeds. Anim. Feed Sci. Technol. 57, 347-358 (1996).

\section{Acknowledgements}

The authors thank the Federal University of Mato Grosso do Sul (UFMS), the National Council for Scientific and Technological Development (CNPq), the Higher Education Personnel Improvement Coordination (CAPES, Finance Code 001), the Mato Grosso do Sul State Education, Science and Technology Development Support Foundation (FUNDECT) and Amireia Pajoara Industry and Commerce.

\section{Author contributions}

N.D.K., L.C.V.I. devised the project. N.D.K., A.G.I. prepared the material. N.D.K., L.C.S.O., E.N.A. methodology. N.D.K., L.C.V.I. writing-original draf. C.C.B.F.I., G.S.D., A.M.D., A.L.C.G., G.T.S. writing-review and editing.

\section{Competing interests}

The authors declare no competing interests.

\section{Additional information}

Correspondence and requests for materials should be addressed to L.C.V.Í.

Reprints and permissions information is available at www.nature.com/reprints.

Publisher's note Springer Nature remains neutral with regard to jurisdictional claims in published maps and institutional affiliations.

(c) (i) Open Access This article is licensed under a Creative Commons Attribution 4.0 International License, which permits use, sharing, adaptation, distribution and reproduction in any medium or format, as long as you give appropriate credit to the original author(s) and the source, provide a link to the Creative Commons licence, and indicate if changes were made. The images or other third party material in this article are included in the article's Creative Commons licence, unless indicated otherwise in a credit line to the material. If material is not included in the article's Creative Commons licence and your intended use is not permitted by statutory regulation or exceeds the permitted use, you will need to obtain permission directly from the copyright holder. To view a copy of this licence, visit http://creativecommons.org/licenses/by/4.0/.

(C) The Author(s) 2021 